\title{
Seabed topography beneath Larsen C Ice Shelf from seismic soundings
}

\author{
A. M. Brisbourne, A. M. Smith, E. C. King, K. W. Nicholls, P. R. Holland, and K. Makinson \\ British Antarctic Survey, High Cross, Madingley Road, Cambridge, CB3 0ET, UK
}

Correspondence to: A. M. Brisbourne (aleisb@bas.ac.uk)

Received: 5 August 2013 - Published in The Cryosphere Discuss.: 15 August 2013

Revised: 22 October 2013 - Accepted: 31 October 2013 - Published: 2 January 2014

\begin{abstract}
Seismic reflection soundings of ice thickness and seabed depth were acquired on the Larsen C Ice Shelf in order to test a sub-ice shelf bathymetry model derived from the inversion of IceBridge gravity data. A series of lines was collected, from the Churchill Peninsula in the north to the Joerg Peninsula in the south, and also towards the ice front. Sites were selected using the bathymetry model derived from the inversion of free-air gravity data to indicate key regions where sub-ice shelf oceanic circulation may be affected by ice draft and seabed depth. The seismic velocity profile in the upper $100 \mathrm{~m}$ of firn and ice was derived from shallow refraction surveys at a number of locations. Measured temperatures within the ice column and at the ice base were used to define the velocity profile through the remainder of the ice column. Seismic velocities in the water column were derived from previous in situ measurements. Uncertainties in ice and water cavity thickness are in general $<10 \mathrm{~m}$. Compared with the seismic measurements, the rootmean-square error in the gravimetrically derived bathymetry at the seismic sites is $162 \mathrm{~m}$. The seismic profiles prove the non-existence of several bathymetric features that are indicated in the gravity inversion model, significantly modifying the expected oceanic circulation beneath the ice shelf. Similar features have previously been shown to be highly significant in affecting basal melt rates predicted by ocean models. The discrepancies between the gravity inversion results and the seismic bathymetry are attributed to the assumption of uniform geology inherent in the gravity inversion process and also the sparsity of IceBridge flight lines. Results indicate that care must be taken when using bathymetry models derived by the inversion of free-air gravity anomalies. The bathymetry results presented here will be used to improve existing sub-ice shelf ocean circulation models.
\end{abstract}

\section{Introduction}

Ice-shelf disintegration is of global significance due to two important processes. Firstly, although the loss of the floating portion of an ice shelf following retreat or break-up has only a minor direct effect on sea level, the removal of the buttressing effect of the ice shelf and the subsequent acceleration of the tributary ice streams can result in a significant contribution to sea level rise (e.g., Rignot et al., 2004; Scambos et al., 2004). Secondly, cold and low-salinity water produced by the basal melting of ice shelves influences Antarctic Bottom Water formation and consequently the properties of the global oceans (Jacobs, 2004). Reduced production of Ice Shelf Water following the loss of an ice shelf decreases the production of bottom water formed by ice shelf-ocean interaction. However, Antarctic Bottom Water production potentially increases through enhanced sea ice production as a result of more open water available for atmosphere-ocean exchange. In some sectors of Antarctica, such as in the South Eastern Weddell Sea, ice shelf melting reduces the salinity to the point where bottom water formation is not possible (Fahrbach et al., 1994).

The susceptibility to break-up of eastern Antarctic Peninsula ice shelves has been highlighted over the last two decades by the well-documented collapse of the most northerly sections of Larsen Ice Shelf, Larsen A in 1995 (Rott et al., 1996; Vaughan and Doake, 1996) and Larsen B in 2002 (Glasser and Scambos, 2008). There is some evidence that the freshwater released after these break-ups has contributed to a significant freshening of the Antarctic Bottom Water produced in this region (Jullion et al., 2013). Larsen C Ice Shelf (Fig. 1), the largest ice shelf on the Antarctic Peninsula at around $50000 \mathrm{~km}^{2}$ (Cook and Vaughan, 2010) 


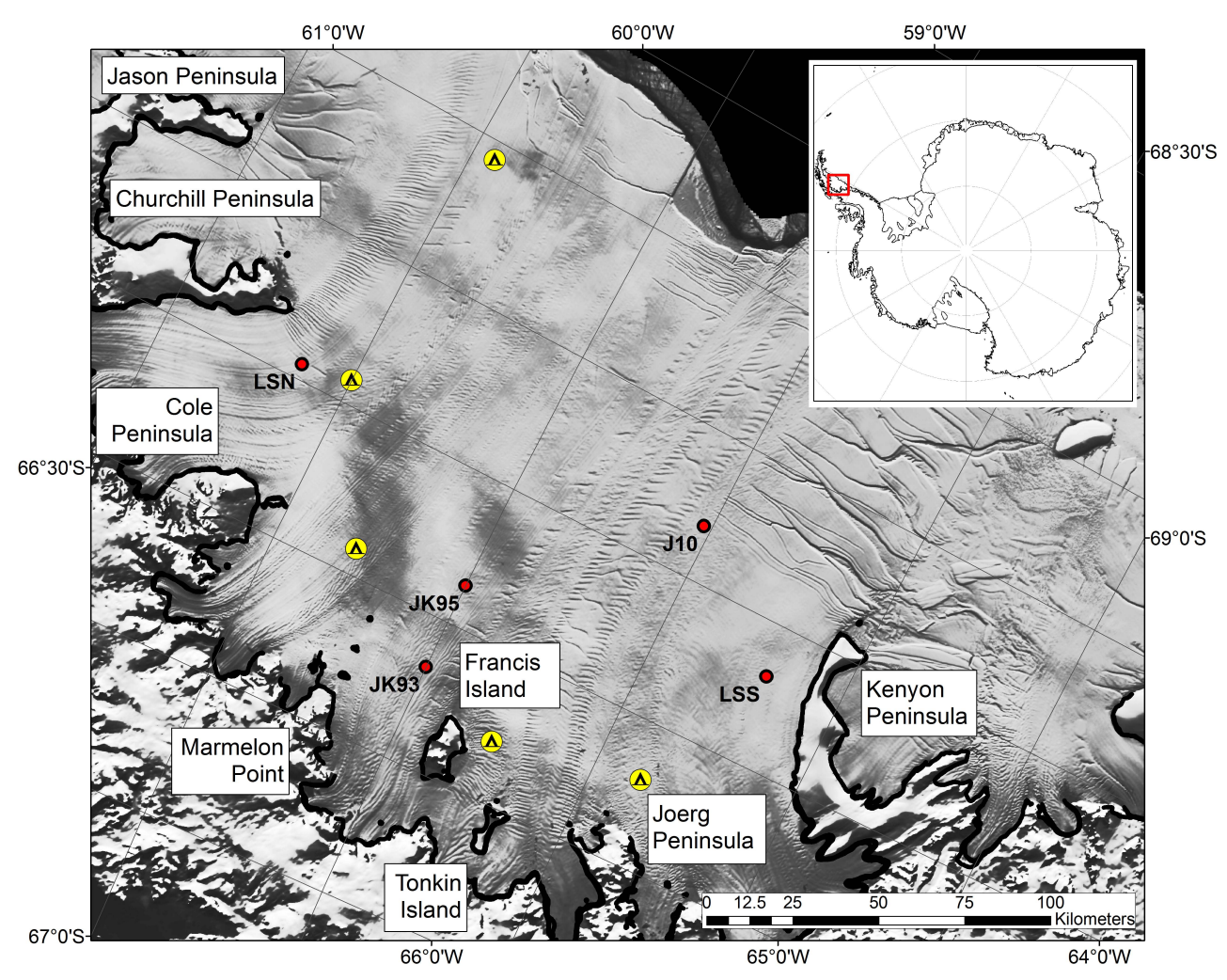

Fig. 1. Larsen C Ice Shelf with MODIS image (Haran et al., 2005) annotated with the main geographical features referred to in the text. Seismic field camps in yellow. Red circles are sites of previously measured ice thickness and water depth: JK93 Seismic (King et al., 1993); JK95 Seismic (Jarvis and King, 1995); LSN/LSS BAS Moorings (Nicholls et al., 2012); J10 Seismic (Kulessa et al., 2010). The grounding line as derived from DInSAR data (Rignot et al., 2011) is represented by the thick black coastline.

lies just to the south of these ice shelves, and is currently just beyond the encroaching $-5^{\circ} \mathrm{C}$ mean annual air temperature isotherm, the proposed heuristic limit of ice-shelf viability (Vaughan and Doake, 1996). Ice-shelf retreat has been attributed to atmospheric warming in a number of cases (Vaughan and Doake, 1996; Rott et al., 1998; Skvarca et al., 1999). Consequently, with the Antarctic Peninsula exhibiting one of Earth's highest rates of atmospheric warming (Vaughan et al., 2003), eventual break-up of the more southerly Larsen C Ice Shelf is likely.

Ice shelf break-up is preceded by thinning, which results from processes at both the surface and the ice base. However, the relative contribution of surface processes and basal melting to the observed thinning of Larsen $\mathrm{C}$ is as yet unresolved. Satellite radar altimeter data indicate that surface lowering of Larsen C has been on-going since at least 1992 (Shepherd et al., 2003; Fricker and Padman, 2012). Several authors suggest that this thinning may be caused by a reduction in firn air, a manifestation of increased surface melting resulting from circumpolar air currents flowing over the peninsula and descending on the eastern side (Holland et al., 2011; Pritchard et al., 2012). Shepherd et al. (2003) argue that a significant component of thinning must result from increased basal melting caused by warmer Weddell Sea Deep
Waters observed at depths greater than the ice-shelf draft. However, Nicholls et al. (2012) presented results from two drill sites which demonstrate that the sub-ice shelf cavity is flushed by water at the surface freezing point, indicating that increased basal melting is unlikely to have contributed to surface lowering.

Accurate knowledge of the bathymetry beneath ice shelves is critical to modelling and understanding the contribution of basal melting to ice shelf thinning and subsequent instability (Jenkins et al., 2010; Grosfeld et al., 1997). Due to the difficulty of mapping the cavity directly, sub-ice shelf bathymetry remains relatively poorly known: radar energy is highly attenuated by sea water and therefore precludes airborne radio echo sounding; direct measurements with autonomous underwater vehicles are expensive and complex. Seismic surveys, although time-consuming, are the only geophysical method available to measure accurately ice thickness, water column thickness and seabed properties. Consequently, a number of seismic surveys have been carried out, and these have provided most of the presently available maps of subice shelf bathymetry (e.g., Determann et al., 1988; Johnson and Smith, 1997; Nost, 2004). 
The importance of sub-ice shelf geometry has led to a number of indirect techniques being used to derive geometry models from sparse observations. Hemer et al. (2006) and Galton-Fenzi et al. (2008) minimised the misfit between ocean-tide models and tidal elevation observations by adjusting sub-ice shelf cavity geometry models for the Amery Ice Shelf. Roy et al. (2005) inverted airborne gravity data to derive water depth and sediment thickness of Lake Vostok, East Antarctica, constrained by available seismic and radar profiles. Similarly, Muto et al. (2013) constrained their aerogravity inversion for bathymetry and sediment distribution beneath Pine Island Glacier with cavity geometry derived from autonomous underwater vehicle tracks. Tinto and Bell (2011) modelled bathymetry beneath Thwaites Glacier in the Amundsen Sea region using known bathymetry to constrain inhomogeneous geology. Of direct relevance to this study, Cochran and Bell (2012) used Operation IceBridge free-air gravity anomaly (FAA) data over the Larsen Ice Shelf. The Parker-Oldenburg technique (Oldenburg, 1974) used in that study relates the observed free-air anomaly to topographic relief superimposed on a horizontal interface. Two variables are permitted in the inversion technique used. Firstly, mean depth to the seabed is fixed to provide the bestmatch at a known point, such as a previous seismic or drill site. Secondly, density contrast is specified. As only one density contrast can be used for the entire model, it is equivalent to assuming a uniform geology. Any lateral variation in gravity anomaly is therefore attributed to lateral bathymetry variation. The sensitivity of the resulting bathymetry model to both these variables can be tested. Cochran and Bell (2012) used previous seismic measurements (King et al., 1993; Jarvis and King, 1995) north of Francis Island (Fig. 1) to constrain the mean depth of the bathymetry model beneath Larsen C. A density contrast of $1.67 \mathrm{~g} \mathrm{~cm}^{-3}$ was assumed based on the regional geological framework.

The bathymetry model presented by Cochran and Bell (2012) exhibits over-deepening along the grounding line and also two broad troughs extending from the grounding line to the ice front. These features could provide conduits for oceanic circulation beneath the entire ice shelf. Mueller et al. (2012) modelled ice-ocean interaction for Larsen C Ice Shelf, predicting basal melt rates using a numerical model with a bathymetry that appears similar to that of Cochran and Bell (2012), and also variants of this bathymetry. They demonstrated the sensitivity of the predicted melt rates to cavity geometry: localised narrowing of the cavity results in significantly elevated melt rates because of local intensification of tidal flow.

In order that the Cochran and Bell (2012) bathymetry map beneath Larsen $C$ could be validated for use in oceanographic modelling, a seismic survey was undertaken in 2012/13 to obtain point measurements of ice and sub-ice shelf water cavity thickness (Fig. 2). Here we present the results of this survey and compare them with those obtained by inversion of the Operation IceBridge gravity data.

\section{Data and methods}

Logistics and time constraints precluded surveying the entire ice shelf in a single field season. Therefore, the bathymetry map of Cochran and Bell (2012) was used to prioritise specific regions of interest in sub-ice shelf circulation models. The Cochran and Bell (2012) cavity geometry (Fig. 2) infers a potential pathway for whole-shelf circulation via overdeepenings along the grounding line. Restrictions to flow along this conduit would significantly alter sub-shelf circulation and therefore basal melt rates. Consequently, a series of point measurements were collected along lines radiating from coastal promontories, where the IceBridge bathymetry model would predict restricted water flow (Fig. 2). Also, a single line was acquired closer to the seaward edge of the ice shelf, between an extreme maximum and an extreme minimum of the cavity thickness as predicted by the gravity inversion. Eighty-seven new seismic measurements of ice thickness and seabed depth were made. Previously, only five insitu measurements have been available (Figs. 1 and 2) (King et al., 1993; Jarvis and King, 1995; Kulessa et al., 2010; Nicholls et al., 2012).

\subsection{Data acquisition and processing}

Seismic soundings were acquired along 10 lines at 3, 5 or $10 \mathrm{~km}$ spacing (Fig. 2). At each site, a $4 \mathrm{~m}$ shot hole was drilled using a hand-operated PICO drill. Charges of 150 to $600 \mathrm{~g}$ of Pentolite high explosive were used and the holes backfilled with loose snow. Twenty-four $40 \mathrm{~Hz}$ georods (Voigt et al., 2013) were deployed at a $10 \mathrm{~m}$ spacing and buried to ensure good coupling and to provide protection from the wind. Two-second records were acquired with a 24 channel Geometrics Geode data logger at $0.125 \mathrm{~ms}$ sample interval.

Seismic reflection quality was highly variable (Fig. 3). In general, the seabed reflector was obvious in the raw seismic records. However, the ice base reflection was not always clear. Where necessary a frequency-wavenumber (F-K) filter was applied to remove unwanted noise (groundroll) which masked the ice base reflection where ice thickness was less than around $270 \mathrm{~m}$ (e.g., Fig. 3b). In some cases, an automatic gain control (AGC) filter was applied to the records to enhance weaker signals later in the records (Fig. 3b). In many cases, the AGC filter emphasises internal multiple reflections from the ice layer which can be used to determine ice thickness when the primary reflection is unclear (return i2 in Fig. 3c).

\subsection{Seismic velocities in ice and water}

As the density of the snow and firn increases with depth so does the seismic velocity. In general, the velocity of solid ice is reached at a depth of $80-100 \mathrm{~m}$. Below this depth the temperature gradient down to the ice-ocean interface results 


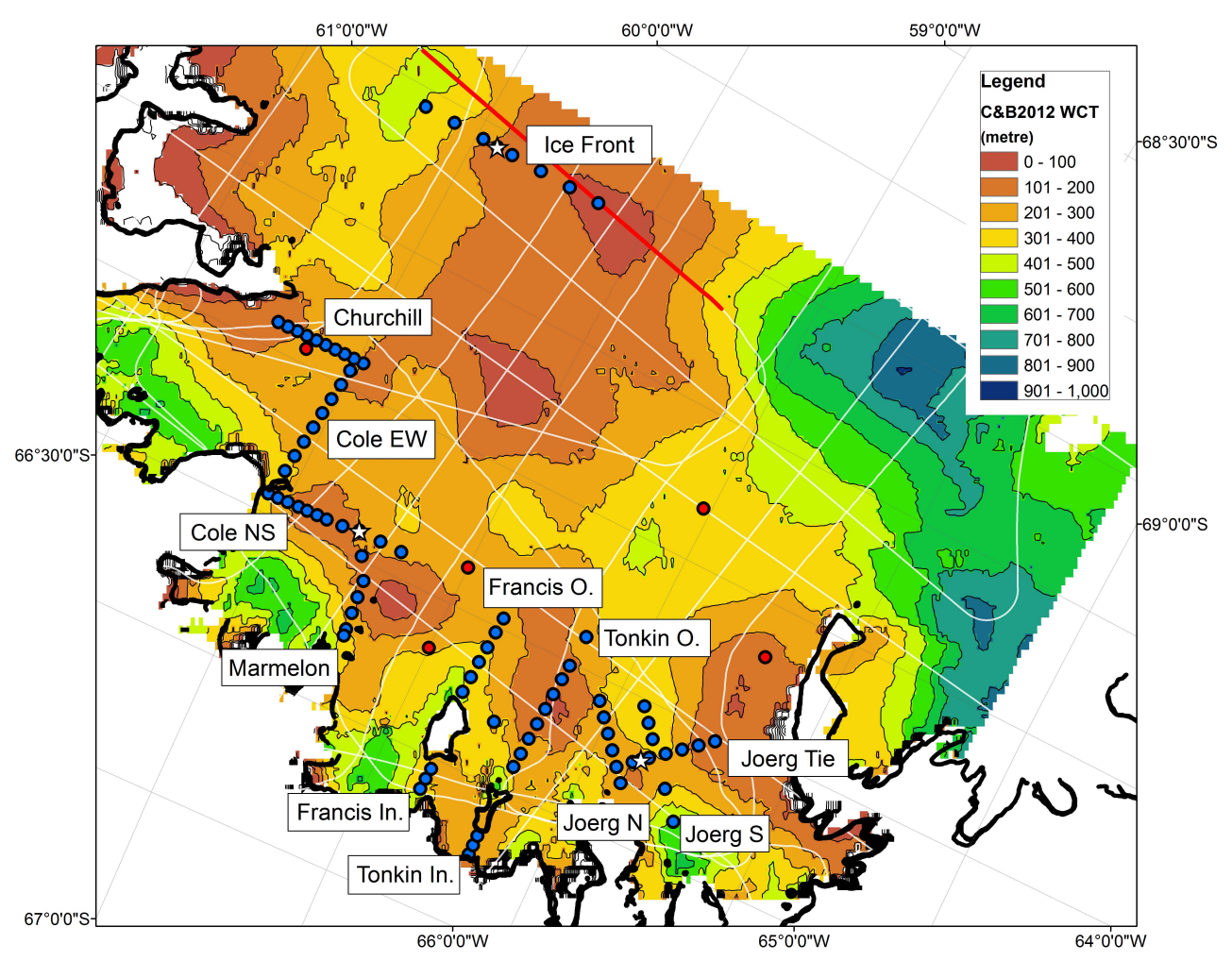

Fig. 2. Seismic reflection acquisition sites presented in Fig. 6 (blue circles) with line names as referred to in the text overlain on the contoured water cavity thickness derived from the inversion of IceBridge free-air gravity anomaly (Cochran and Bell, 2012). White stars indicate the three shallow seismic refraction sites where velocity-depth profiles were derived. Previous sites as per Fig. 1 (red circles). The grounding line as derived from DInSAR data (Rignot et al., 2011) is represented by the thick black coastline. The IceBridge flight line segment towards the ice front referred to in the text is indicated by the red line, all other IceBridge flight lines are in white (an edited version of which was used in the FAA inversion).

in a velocity decrease with depth. From the surface down to the depth of maximum velocity, seismic reflection traveltimes are converted to depth using measured velocity profiles. In order that a velocity-depth profile for the ice column could be established, three shallow seismic refraction surveys were carried out (Fig. 2). A series of surface shots were recorded into georods spaced at 2.5 to $610 \mathrm{~m}$ offset and the first arrivals picked (Fig. 4a). Arrival times are converted to a velocity-depth relationship using the method described by Kirchner and Bentley (1990). This method relies on a monotonic increase in velocity with depth. Seasonal melting of the near-surface, as previously observed on Larsen C (Fahnestock et al., 2002), could cause ice layers that potentially invalidate this assumption. However, smooth and increasing traveltime picks (Fig. 4a) observed at all three shallow refraction sites indicate that the assumption is valid in these cases: in general, at the seismic wavelength $(>10 \mathrm{~m})$ velocities increase uniformly with depth. For each seismic survey point, the velocity profile corresponding to the nearest shallow refraction survey was used. Density-depth profiles are derived from the P-wave velocity using the empirical relationship of Kohnen (1972). Below the maximum depth of penetration obtained by seismic refraction surveys, temperature measurements from within the ice column obtained from the boreholes discussed by Nicholls et al. (2012) are used to derive the mean seismic velocity using the temperaturevelocity relationship of Kohnen (1974). Downhole measurements indicate an ice temperature of $-13^{\circ} \mathrm{C}$ at $100 \mathrm{~m}$ depth, equivalent to a seismic velocity in ice of $3825 \mathrm{~m} \mathrm{~s}^{-1}$. A shelf-base temperature from conductivity-temperature-depth (CTD) measurements of $-2{ }^{\circ} \mathrm{C}$ (Nicholls et al., 2012) indicates an ice velocity of $3800 \mathrm{~m} \mathrm{~s}^{-1}$ at the ice base. Therefore, below $100 \mathrm{~m}$ depth a mean seismic velocity in the ice of $3812 \mathrm{~m} \mathrm{~s}^{-1}$ is used. Scatter in traveltime picks and insufficient spread-length preclude well-constrained deep velocities from the refraction data. This velocity is therefore also used to constrain velocities at depths below $100 \mathrm{~m}$ in the inversion of the seismic refraction traveltimes.

A mean seismic velocity in the water column of $1445 \pm 1 \mathrm{~m} \mathrm{~s}^{-1}$ was derived from CTD measurements made close to the Churchill Peninsula in the north and the Kenyon Peninsula in the south (Nicholls et al., 2012). 

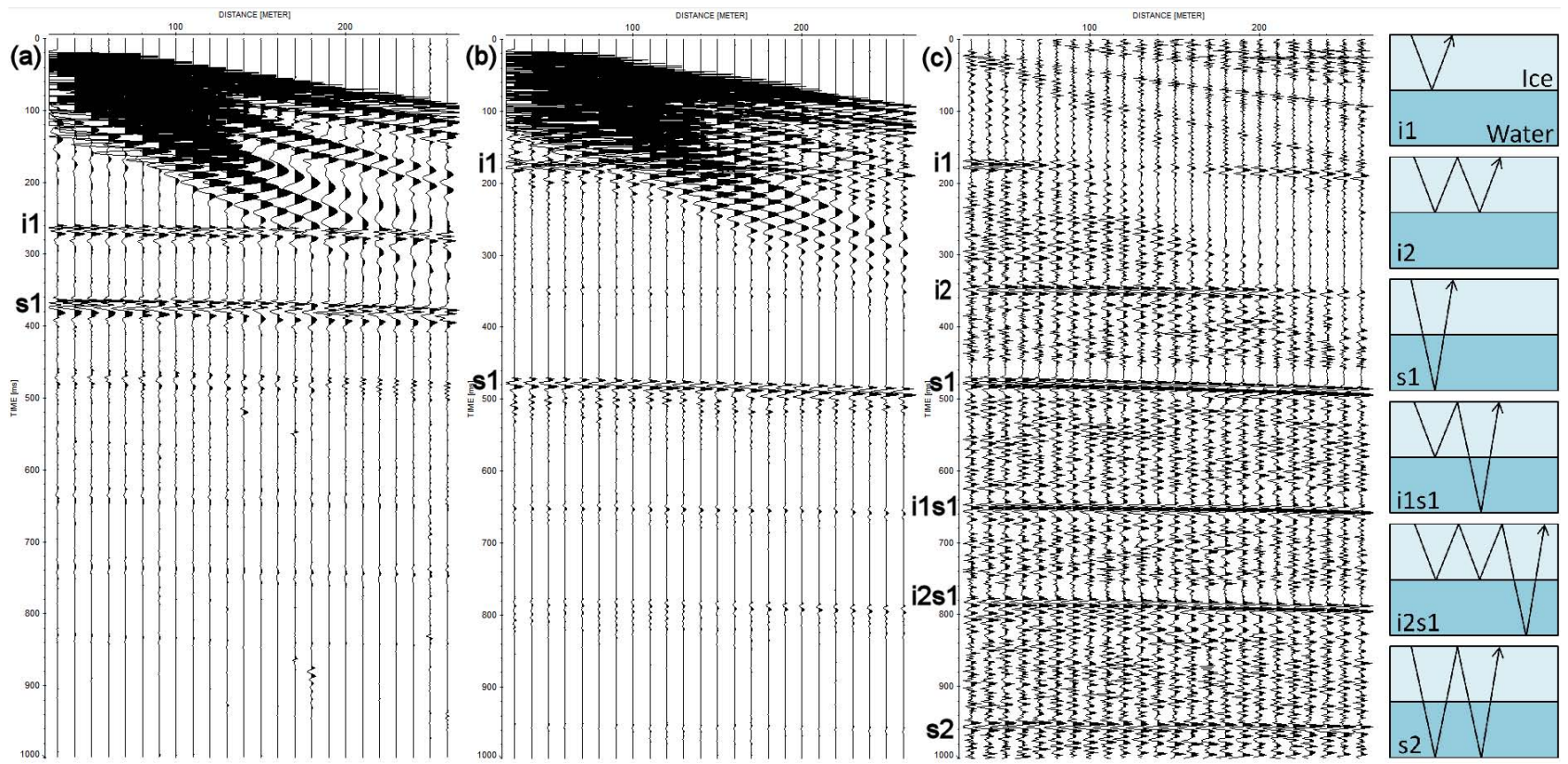

Fig. 3. Example 24-channel seismic records with multiples: (a) Raw data from a single Francis Island site with clear ice-base (i1) and seabed (s1) direct arrivals, multiples also present but weak; (b) Raw data from a single Churchill Peninsula site with clear s1 arrival but the direct ice-base arrival (i1) is obscured by groundroll noise; (c) as b but with a frequency-wavenumber filter to remove groundroll and AGC filter to enhance weaker signals. Direct reflections and multiples annotated as per the schematic. Raypaths on the schematic are for illustrative purposes only and do not represent true raypaths, which are significantly distorted by the velocity gradient of the firn layer and velocity contrast at the ice base.
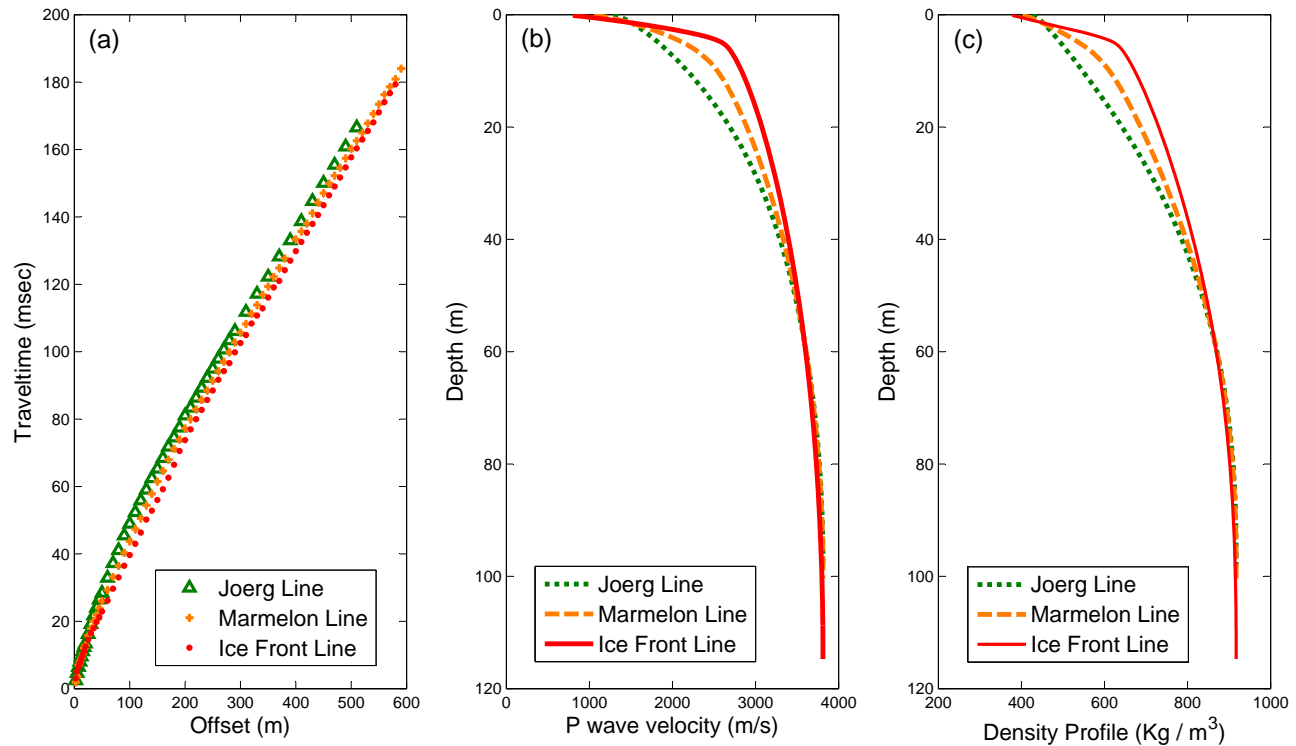

Fig. 4. (a) Traveltime against offset for the 3 seismic refraction experiments indicating a monotonic velocity increase with depth, inferred from the continuous increase in traveltime with offset; (b) seismic velocity-depth profiles derived using the method of Kirchner and Bentley (1990) for the three seismic refraction profiles. Velocities at depths beyond $100 \mathrm{~m}$ are constrained by temperature profiles discussed by Nicholls et al. (2012) and the velocity-temperature relationship of Kohnen (1974); (c) density-depth profiles derived using the method of Kohnen (1972). 
The velocity-depth profiles are presented in Fig. $4 \mathrm{~b}$ and the derived density-depth profiles in Fig. 4c. Densification rates were higher down to pore close-off towards the ice front than close to the grounding line (Ice Front compared to Marmelon, both sites are at a similar latitude). Also, firn densification rates were higher in the north than the south (Marmelon compared to Joerg, both at a similar longitude). Integrating the density profiles produces a total firn-air content of $11.3 \pm 1.3 \mathrm{~m}$ at the ice-front site, $12.9 \pm 1.3 \mathrm{~m}$ at the Marmelon site and $14.4 \pm 1.3 \mathrm{~m}$ at the Joerg site, compared with Holland et al.'s (2011) estimates of $11.0 \pm 1.8 \mathrm{~m}$, $10.0 \pm 1.8 \mathrm{~m}$, and $12.7 \pm 1.8 \mathrm{~m}$ respectively, all of which agree within error bars. These results are consistent with a higher degree of melting of firn in the north than the south, as found in the borehole measurements of Nicholls et al. (2012) and the firn air content variation presented by Holland et al. (2011).

\subsection{Uncertainties}

The most significant assumption made in the derivation of depth from ice base and seabed reflections is a flat and planar reflector. Unless the line of georods is directly along strike of any dipping interface the moveout of the returns (variation of arrival time with offset due to ray path geometry) will deviate from that expected. Such discrepancies become clear when picking the traveltimes of the reflections. In the majority of cases the moveout deviation was $<10 \mathrm{~m} \mathrm{~s}^{-1}$ at $260 \mathrm{~m}$ offset. During the field campaign, at a site where a $10 \mathrm{~m} \mathrm{~s}^{-1}$ deviation in normal moveout (NMO) at $250 \mathrm{~m}$ offset was observed, an orthogonal line was shot: this allows determination of slope and thus allows us to quantify the uncertainty associated with non-standard moveout. Results indicate that although moveout and arrival times varied with shot offset and array orientation, a maximum of $\pm 8 \mathrm{~m}$ variation in seabed depth could be expected.

Nost (2004) presented an analysis of the uncertainties associated with a sloping seabed, indicating a slope of 0.205 $\left(\sim 12^{\circ}\right)$ introduces an uncertainty of $\pm 60 \mathrm{~m}$ for ice and water cavity thicknesses of $500 \mathrm{~m}$ each. The maximum largescale dip of reflectors along the profiles acquired here $\left(\sim 2.5^{\circ}\right.$ along the Francis Offshore Line) indicates that assuming a horizontal and planar seabed is reasonable and does not significantly increase uncertainties. Without carrying out a number of shots at each site or at the very least utilising an Lshaped array (Roethlisberger, 1972) it is impossible to determine interface geometry accurately and therefore we made the assumption that interface topography is negligible.

Picking errors in the seismic reflection data are in general $<0.5 \mathrm{~ms}$. Uncertainties in the seismic velocities in the firn layer cannot readily be quantified here due to the statistically small number of measurements made. However, using a similar technique and multiple sites Kirchner and Bentley (1990) estimate a velocity uncertainty of $\pm 60 \mathrm{~m} \mathrm{~s}^{-1}$ near the surface, reducing to $\pm 30 \mathrm{~m} \mathrm{~s}^{-1}$ at $10 \mathrm{~m}$ depth and $\pm 15 \mathrm{~m} \mathrm{~s}^{-1}$

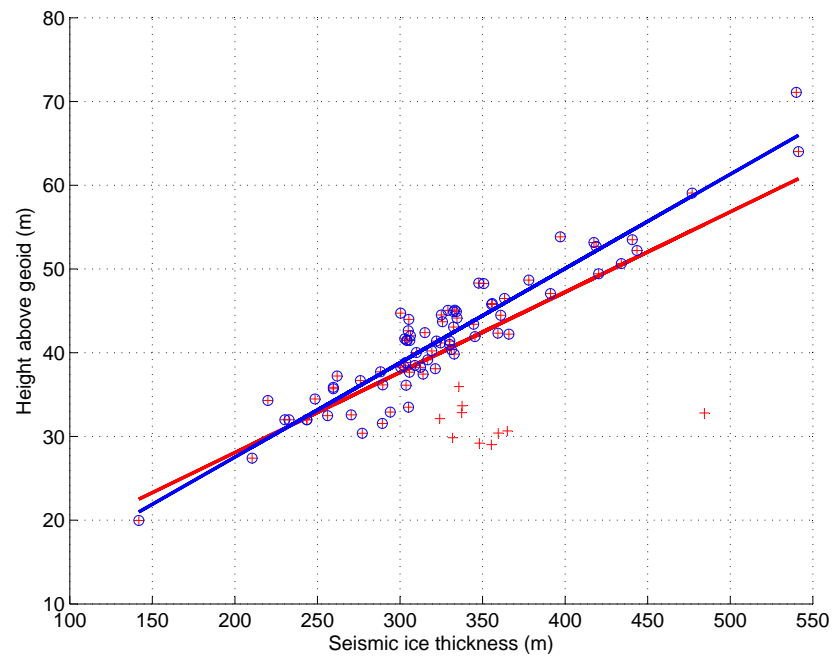

Fig. 5. Geoid-corrected height (h) against seismic ice thickness $(H)$. Red crosses represent all sites. Blue circles highlight those sites deemed unaffected by the proximity of the grounding line, i.e., fully floating excludes sites with negative firn correction calculated from elevation and seismic thickness as per Griggs and Bamber (2009). The red line is the linear fit to all data; the blue line is the linear fit to fully-floating sites (Fit: $\mathrm{h}=(0.113 \pm 0.005) \mathrm{H}+(5.003 \pm 1.525)$; $R^{2}=0.89$ ). No correction for tidal variation in surface elevations was made and this therefore contributes to the scatter observed in the data ( $\pm 2 \mathrm{~m}$ at the Churchill Camp, Fig. 1).

at $50 \mathrm{~m}$ depth. Our use of in situ temperature measurements provides greater accuracy beyond these depths.

Booth et al. (2010) used semblance analysis of seismic reflection data from Larsen C Ice Shelf (Site J10 in Fig. 1), combined with radar sections constraining layer thickness, to imply a marine ice P-wave velocity of $2162 \mathrm{~m} \mathrm{~s}^{-1}$ ( $40 \%$ lower than meteoric ice). This was shown to reduce the overall root-mean-square (rms) velocity of the ice base reflector by $10 \%$ which would result in an overestimation of ice thickness of $10 \%$ for that particular location. In this study it is not possible to determine the thickness of any marine ice present. We therefore assume a meteoric ice velocity for the entire ice column. Ice thickness measurements determined here are however consistent with surface elevation measurements (Fig. 5) indicating that this assumption does not significantly bias the results.

At each site a dual-frequency Leica 1200 or GS10 GPS receiver was used to measure ellipsoidal surface heights. The EIGEN-GL04C geoid model (Forste et al., 2008) was used to correct measured ellipsoidal elevation to the height above the geoid, which was then subtracted from the ice thickness to determine ice draft. The shelf ice rises and falls with the ocean tides, which were not corrected for in this study. This will contribute some time-dependent variation in both the surface height measurements and the water cavity thickness. A tidal range of over $4 \mathrm{~m}$ was recorded at the Churchill Camp, indicating an implicit variation in cavity thickness of 
$\pm 2 \mathrm{~m}$. This is insignificant with respect to other uncertainties and is therefore not corrected for in this study.

This results in an uncertainty in both the ice thickness and water column thickness of 5 to $10 \mathrm{~m}$ depending on the reflection quality and moveout, or a seabed depth uncertainty of around $10 \mathrm{~m}$, increasing to $20 \mathrm{~m}$ in areas where reflector quality is diminished. Ice thickness could be greatly underestimated where a significant thickness of low-velocity marine ice is present. Importantly, the thickness of the water column derived from the seismic data is independent of the ice velocity-depth profile used.

Cochran and Bell (2012) attribute uncertainties to their gravimetrically derived model of as much as $100 \mathrm{~m}$ due to the possible presence of low-density sediments, especially in the deep troughs.

\section{Results}

\subsection{Ice thickness and draft}

Figure 5 presents the ice thickness derived from seismic soundings against geoid-corrected surface elevation. As expected, there is a clear linear relationship between surface elevation and thickness for floating ice. However, there are some outliers from this general relation, which we suggest to be points that are not freely floating. Using the derived surface elevation and seismic ice thicknesses, we calculate the firn-air correction required to satisfy the assumption that the ice is floating in hydrostatic equilibrium (Griggs and Bamber, 2009). Where the required firn-air correction is negative, we contend that the ice is not freely floating. A number of outliers are observed where proximity to the grounding line precludes fully-floating ice (Marmelon Line, proximal to Tonkin Island and the Cole Peninsula). Due to the different firn profiles and melting histories between north and south we could expect different elevation-thickness relationships, as reflected in the refraction seismic velocity-depth profiles. The seismically measured ice thickness is in good agreement with the thickness measurements derived from surface elevations and airborne radar soundings (Holland et al., 2009) with an rms difference of $26.7 \mathrm{~m}$ for the 76 fully floating sites. Ice thickness measurements are not affected by tidal height.

\subsection{Results: Bathymetry and sub-ice shelf cavity thickness}

Profiles comparing ice draft and water cavity thickness from the seismic measurements with those derived by the free-air gravity anomaly inversion are presented in Fig. 6 . There are some significant discrepancies in the gravity inversion results when compared with the seismically measured depths. The rms error of the gravity inversion at 87 seismic sites is $162 \mathrm{~m}$ in bathymetry and $143 \mathrm{~m}$ in sub-ice shelf cavity thickness. Errors in the cavity thickness determined by the gravity inversion range from less than $10 \mathrm{~m}$ up to $320 \mathrm{~m}$.

\subsubsection{Ice front}

The gravimetric results for the ice front line indicate a significant shallowing in the bathymetry from north to south (Fig. 6a), resulting in a water cavity which reduces from around $380 \mathrm{~m}$ in the north to less than $100 \mathrm{~m}$ in the south. However, the seismic results indicate a uniform water cavity thickness of around 220 to $240 \mathrm{~m}$, resulting in an rms error of $103 \mathrm{~m}$ for the gravimetrically derived bathymetry along this line. Ice draft is consistent between the methods.

\subsubsection{Churchill Peninsula}

There is good agreement between the gravimetrically and seismically derived cavity thickness along the Churchill Line, as presented in Fig. 6b, with an rms error of $20 \mathrm{~m}$ in bathymetry.

\subsubsection{Cole Peninsula - EW and NS}

Although there is general agreement between the observed and modelled depths for the two profiles radiating from the Cole Peninsula (Figs. 6c and d), there is no evidence in the seismic data for the thick sub-ice shelf cavity close to the peninsula. Also, on the north-south line the cavity narrows significantly within $10 \mathrm{~km}$ of the peninsula, to $<100 \mathrm{~m}$, a feature not observed in the gravity inversion results.

\subsubsection{Marmelon Point}

There is a significant discrepancy between the gravity results and the seismic observations east of Marmelon Point (Fig. 6e). The seismic sites close to the point indicate that the ice is most likely grounded in this area. This result is supported by field observations of strand cracks (Swithinbank, 1955) between the seismic sites. Furthermore, the DInSAR grounding line (Rignot et al., 2011) indicates that islands are buried within the ice shelf in this region (visible in Fig. 1, directly east of Marmelon Point). The size of these sub-ice features is likely below the resolution of the gravity data. However, the difference in the water cavity implied by the two methods $(\sim 200 \mathrm{~m})$ is significant. The lateral resolution of the Cochran and Bell (2012) gravity inversion is determined by the flight-line spacing (areas $>10 \mathrm{~km}$ from data points masked) and flight speed (a low-pass filter results in a resolution scale of $\sim 5 \mathrm{~km}$ ). Anomalies below these dimensions are resolved at reduced amplitude. Features such as the submerged islands off Marmelon Point, which are in the subkilometre dimension range, are therefore unlikely to be well resolved in the gravity inversion.

\subsubsection{Francis Island - inshore and offshore}

The seismic results indicate that although not grounded between the peninsula and Francis Island, the water cavity is in general $<100 \mathrm{~m}$ thick (Fig. $6 \mathrm{~g}$ ), and relatively thin just 


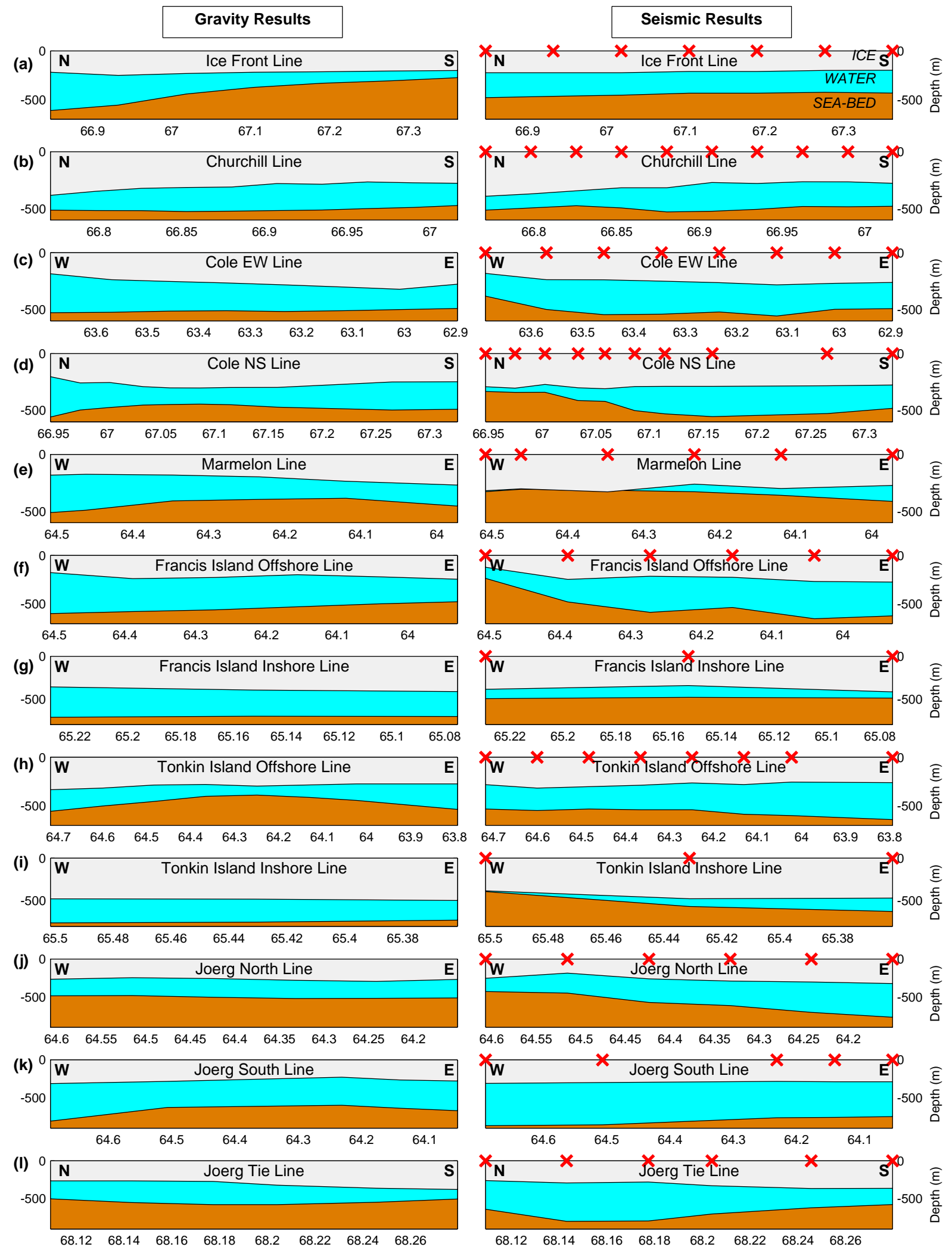

Fig. 6. Ice and sub-ice shelf cavity profile pairs comparing Cochran and Bell (2012) gravity inversion (left) and seismic (right) results. Red crosses indicate locations of seismic measurements. Vertical exaggeration varies between plots. The horizontal coordinate is latitude (S) or longitude (W) as appropriate. 
offshore of Francis Island (Fig. 6f). The results of Cochran and Bell (2012) imply a $>400 \mathrm{~m}$ cavity in both these areas.

\subsubsection{Tonkin Island - inshore and offshore}

Similar to Francis Island, and again contrary to the gravity inversion, the cavity is $<100 \mathrm{~m}$ thick between Tonkin Island and the mainland (Fig. 6i) but thickens eastwards offshore of the island (Fig. 6h).

\subsubsection{Joerg Peninsula}

The gravity inversion results indicate a deep but narrow trough running NE-SW to the south of the Joerg Peninsula. The seismic results confirm that the trough is present but is significantly broader than expected (Figs. 6j-1).

\section{Effect of lateral density variations on free-air anomaly inversion}

Non-uniqueness in the inversion of gravity data is a result of the trade-off between the magnitude, geometry and depth of a subsurface density contrast. A priori knowledge, such as likely lithology, structure and density contrasts, is therefore essential to constrain uniquely inversions for subsurface structure. With knowledge of water column thickness, and constrained by regional geological structure, gravity data over subglacial lakes or ice shelves have been inverted for density contrasts in the sub-surface (e.g., Roy et al., 2005; Muto et al., 2013). Similarly, a priori knowledge of subsurface density contrasts is necessary to determine uniquely the seabed topography from gravity data acquired over an ice shelf. Due to the lack of knowledge of subsurface structure in the region, Cochran and Bell (2012) assume that the seafloor beneath Larsen $C$ consists of volcanic sequences overlain by a negligibly thin or discontinuous layer of sediments. However, to the west of the Antarctic Peninsula, Bart and Anderson (1995), for example, demonstrate that a series of glacial episodes resulted in a complex offshore stratigraphy. The bathymetry results presented here demonstrate that sub-ice shelf cavity models derived by the inversion of airborne freeair gravity anomalies are subject to significant error and can introduce bathymetric features which are not present. Where the assumption of a uniform geology is incorrect, i.e., a subsurface density contrast is present, spurious bathymetric features will always be introduced. Complex stratigraphy north of the Jason Peninsula, offshore from the former Larsen B Ice Shelf, was presented by Sloan et al. (1995). By extrapolating from geology described onshore to interpret marine seismic sections, volcanics appear to dominate the western margin of the former Larsen B Ice Shelf. However, further offshore significant marine, glacial-marine and till deposits are inferred, including large scale cut-and-fill geometries and deposition sequences consistent with ice stream retreat.
To demonstrate the non-uniqueness of the gravity inversion we modelled a simple 2-D anomaly, i.e., a linear feature striking perpendicular to a survey line (Fig. 2). The method of Talwani et al. (1959) is used to derive the gravity anomaly of arbitrary polygons. For example, a potentially realistic model is sediment filled channels at either end of the ice front flight line, separated by a sill of volcanics. Assuming unconsolidated sedimentary infill of $1.9 \mathrm{Mg} \mathrm{m}^{-3}$ over volcanics of $2.7 \mathrm{Mg} \mathrm{m}^{-3}$ (Fig. 7), modelling indicates an infilled channel of around $800 \mathrm{~m}$ depth is sufficient to produce the $25 \mathrm{mgal}$ anomaly observed along the ice front flight line segment. More consolidated, and hence higher density, sediments require a deeper infill layer. For example, infill of $2.3 \mathrm{Mg} \mathrm{m}^{-3}$ would require the sediment to extend to depths of $2500 \mathrm{~m}$ beneath the seabed. Such sediment thicknesses are not unrealistic and at the shallower end of the scale are comparable to seabed depths indicated near the grounding line. Potentially, this anomaly is an extension of the northsouth gravity high which manifests itself as incoherent hyperbolic reflections in marine seismic reflection data, attributed to Jurassic volcanics by Sloan et al. (1995) and Smith and Anderson (2010). This simple 2-D model illustrates the non-uniqueness of the gravity inversion method for deriving bathymetry where subsurface geology is unconstrained: lateral variation in the subsurface density contrast or variable bathymetry over a uniform density can produce an identical free-air gravity anomaly.

\section{Implications for sub-ice shelf ocean circulation and basal melting}

The effects of significant topographic features in the sub-ice shelf cavity have previously been demonstrated by Mueller et al. (2012), who showed the differences in modelled basal melt rates that result from using different sub-ice shelf cavity geometries. In the eastern sector of the gravimetrically derived Larsen $\mathrm{C}$ bathymetry there is a narrowing of the cavity to $<100 \mathrm{~m}$ near the ice front south of $67^{\circ} \mathrm{S}$ (Fig. 2). Although the bathymetry used by Mueller et al. (2012) was derived by extrapolation from offshore bathymetry, it also features a similar narrowing, slightly to the north but in general consistent with Cochran and Bell (2012). Mueller et al. (2012) predict a $\sim 2 \mathrm{~m} \mathrm{a}^{-1}$ melt rate as a result of rapid tidal flow through this narrow cavity in the northeast region, compared with a background rate of $<0.2 \mathrm{~m} \mathrm{a}^{-1}$. Mueller et al. (2012) also tested a bathymetry with a minimum $350 \mathrm{~m}$ water cavity, more closely emulating the seismic observations towards the ice front. Predicted basal melt rates towards the ice front were significantly reduced in the thicker cavity, by as much as $2.3 \mathrm{ma}^{-1}$. This result is more consistent with observed ice shelf draft, since localised melt rates of $\sim 2 \mathrm{~m} \mathrm{a}^{-1}$ would be expected to be reflected in thinning, and thus lower ice surface topography, in the northeastern area of the ice shelf. 
(a)

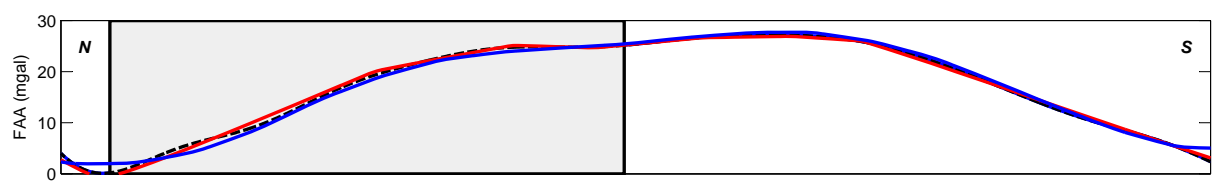

(b)

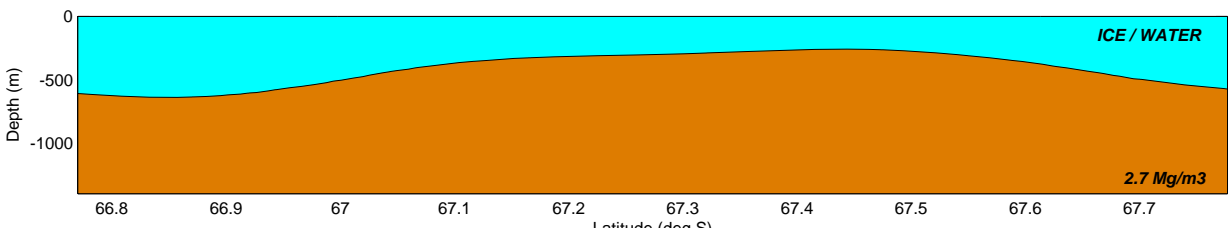

(c)

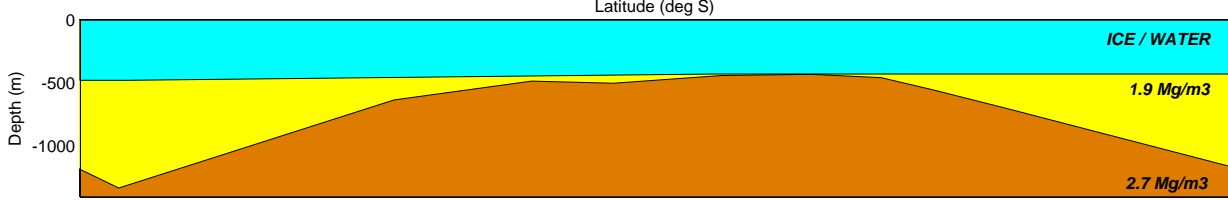

Fig. 7. Modelling of the IceBridge free-air gravity anomaly using the method of Talwani et al. (1959): (a) Black dashed line: measured IceBridge FAA; Blue line: modelled FAA with Cochran and Bell (2012) bathymetry model and constant sub-surface density of $2.7 \mathrm{Mg} \mathrm{m}^{-3}$; Red line: modelled FAA assuming $1.9 \mathrm{Mg} \mathrm{m}^{-3}$ sediment over $2.7 \mathrm{Mg} \mathrm{m}^{-3}$ basement and bathymetry as derived by seismic survey (seabed assumed laterally invariant south of last shot point). The length of the IceBridge line coincident with the seismic line is outlined by the grey box (i.e., where bathymetry is constrained by seismic measurements); (b) Cochran and Bell (2012) bathymetry from FAA inversion; (c) Simple 2-D model of sediment infill along the IceBridge flight line.

The gravity-derived cavity model also implies a consistently thick water column along the grounding line, potentially presenting a route for whole-shelf oceanic circulation, readily allowing mixing between the northern and southern ends of the cavity. However, the results presented here indicate that there are significant barriers to flow at Marmelon Point and around Francis and Tonkin Islands. This is consistent with the preferred ocean circulation scenario of Nicholls et al. (2012) who propose that the southern and northern parts of the shelf cavity are ventilated from sources crossing beneath the ice front at different locations, rather than wholeshelf circulation via the grounding line cavity.

\section{Marine ice beneath Larsen C}

A qualitative correspondence between ice base reflector quality and proposed areas of marine ice freeze-on (Holland et al., 2009) was observed (Fig. 8). In the Holland et al. (2009) study the presence of marine ice was inferred from the absence of basal reflections in radar data where a surface return was obtained. Freeze-on results in a mushy transitional interface (Lewis and Perkin, 1986; Craven et al., 2009), rather than a sharp reflector, and would therefore result in reduced seismic reflection amplitude. There are however a number of other factors that can contribute to reflector amplitude: source coupling, receiver coupling, attenuation within the ice column, reflector geometry, the presence of water-filled crevasses near the ice-base and acoustic impedance contrast across the reflector. The correspondence observed here indicates that at the early stages of marine ice freeze-on, where forming close to the grounding line in shallow-draft areas be- tween glacier flow units (Holland et al., 2009), the interface is not a sharp boundary. Further from the grounding line the freeze-on mechanism appears to cease and this transition becomes more abrupt, resulting in more obvious ice-base seismic reflections.

\section{Conclusions}

Seismic measurements have been acquired at 87 sites across Larsen C Ice Shelf to constrain ice thickness and sub-ice shelf water column thickness. Most of our seismic reflection data from Larsen Ice Shelf are of good quality, reflections from the ice-base and seabed are clear, and the traveltimes of these reflections can be picked precisely. At a few stations, the ice-base reflection is not easy to identify and the main uncertainty in the ice thickness measurement at these locations arises from this. In these cases, standard processing techniques can be used to increase the signal-to-noise ratio and improve the identification of primary reflections and their multiples. Another source of error in the ice thickness measurements comes from uncertainty in the seismic velocity, which must be derived using seismic refraction surveys and a simple temperature-depth model. Variations in the seismic velocities are observed across Larsen Ice Shelf, consistent with varying degrees of melting and firn compaction. Where present, seabed topography cannot be quantified unambiguously without detailed site surveys. The moveout of reflections can however be used to estimate uncertainty.

On Larsen C Ice Shelf, our seismic measurements indicate an rms error of $162 \mathrm{~m}$ in the bathymetry derived from airborne gravity inversion, and $143 \mathrm{~m}$ in the sub-ice shelf cavity 


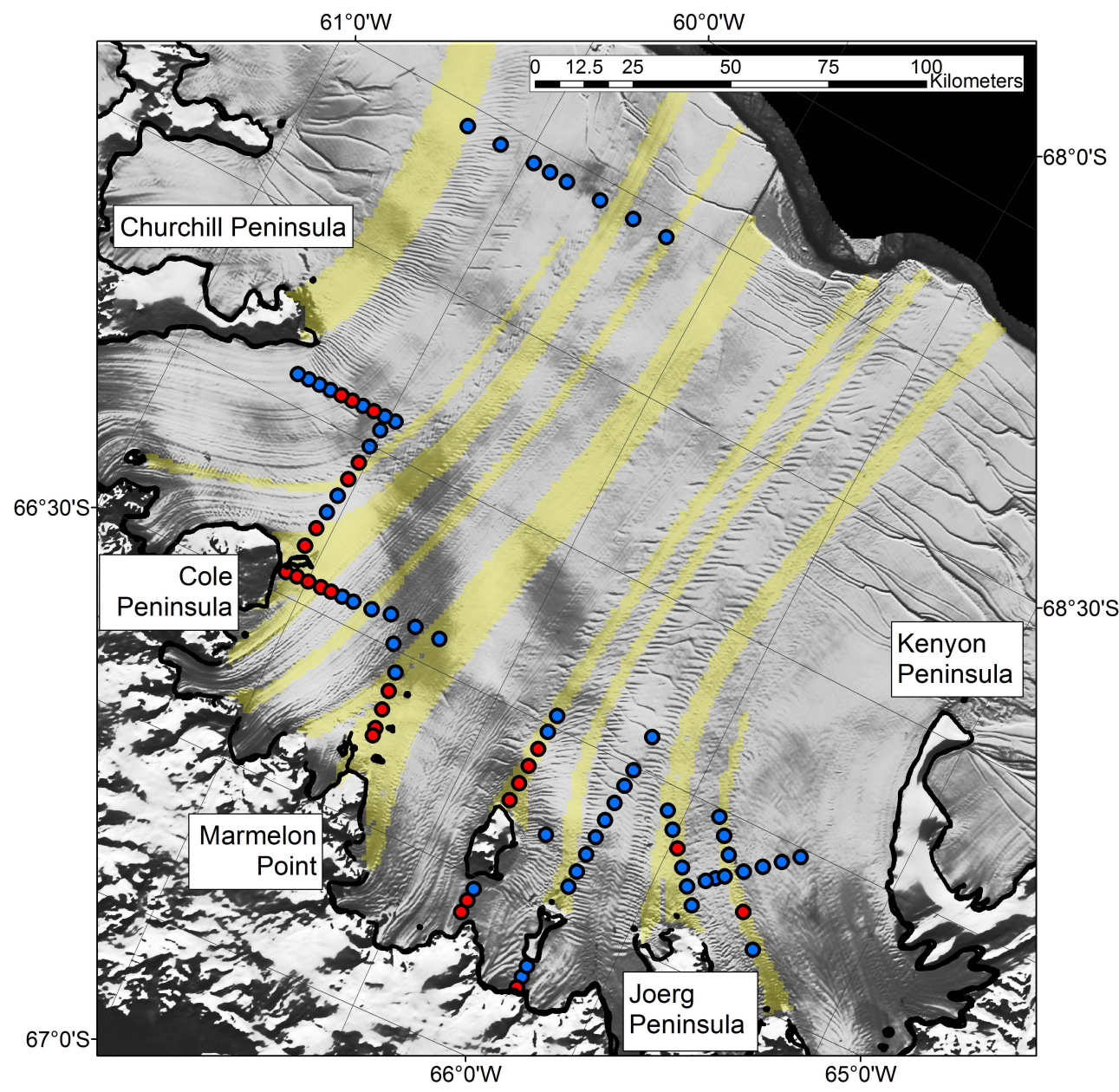

Fig. 8. Proposed marine ice bands in yellow (Holland et al., 2009) over MODIS imagery (Haran et al., 2005). Seismic sites with good icebase reflections are in blue and poor ice-base reflections in red. The marine ice is formed close to the grounding line just offshore from major promontories. There is strong correspondence between sites with poor ice-base reflections and the proposed areas of marine ice formation.

thickness. Within the seismic survey areas, significant errors exist in the gravity-derived model in both the detail and the regional nature of seabed topography. There is however good agreement with ice draft observations from airborne radio echo sounding, with an rms error of $26.7 \mathrm{~m}$.

The seismic results indicate that beneath most of the ice shelf out to its eastern edge, there are no seabed features that will inhibit or concentrate water circulation. In contrast, closer to the grounding line (western edge of the ice shelf), the seismic results indicate restricted, or even zero, cavity thickness, forming significant barriers to ocean circulation, especially close to the Cole Peninsula, Marmelon Point and both Francis and Tonkin Islands. This is consistent with the preferred circulation hypothesised by Nicholls et al. (2012) based on oceanographic data from two boreholes.

Mueller et al. (2012) demonstrated the oceanographic significance of the bathymetric features introduced by the gravity inversion model. A narrowing of the sub-ice shelf cavity towards the ice front introduced basal melt rates as high as $\sim 2 \mathrm{~m} \mathrm{a}^{-1}$. However, a model which more closely resembles the seismic results precludes such high basal melt rates. Such high melt rates are not consistent with observations of ice surface topography.

In this paper we do not re-invert the IceBridge gravity data for seabed bathymetry using the true, seismically-derived bathymetry for improved control. That remains for a future study, preferably with more seismic data to give a more complete coverage of the ice shelf. In this case, the gravity data will improve interpolation between the seismic stations, rather than being the sole source of derived bathymetry. It is also possible to model the free-air anomaly using the seismically derived bathymetry to indicate sub-bed geological structure. Using the derived bathymetry along with typical sedimentary and igneous rock densities, we have demonstrated that realistic models of infilled sedimentary channels produce gravity anomalies similar to those observed over Larsen Ice Shelf. It is clear that to obtain a more reliable model of the bathymetry of the Larsen $\mathrm{C}$ Ice Shelf region 
from gravity inversion, a more realistic implementation of the regional geology is required. As such, any future seismic acquisition campaigns could be modified to acquire data which could constrain seabed properties and potentially discriminate areas of significant sedimentary cover.

The inshore ends of proposed marine ice bands (Holland et al., 2009), resulting from freeze-on at the base of the ice shelf are consistent with sites where the ice base seismic reflection is difficult to resolve. This result would be expected where frazil ice is forming a more diffuse ice-water interface (Craven et al., 2009).

Acknowledgements. This work was funded by UK's Natural Environment Research Council (NERC) and the British Antarctic Survey (BAS). Field support was provided by BAS. We thank Dave Routledge for his invaluable assistance in the field and with data acquisition. Data are available from the author. The authors thank Leo Peters and one anonymous reviewer for their constructive comments.

Edited by: R. Bingham

\section{References}

Bart, P. J. and Anderson, J. B.: Seismic record of glacial events affecting the Pacific margin of the northwestern Antarctic Peninsula, Ant. Res. Series, 68, 75-95, 1995.

Booth, A. D., Kulessa, B., King, E. C., Clark, R. A., Jansen, D., Sammonds, P., and Luckman, A.: Physical properties of meteoric and marine ice in Larsen C Ice Shelf, Antarctic Peninsula, from $\mathrm{Q}$ and AVA analyses of reflection seismic data, EGU General Assembly, Vienna, Austria, 2010, EGU2013-6531, 2013.

Cochran, J. R. and Bell, R. E.: Inversion of IceBridge gravity data for continental shelf bathymetry beneath the Larsen Ice Shelf, Antarctica, J. Glaciol., 58, 540-552, 2012.

Cook, A. J. and Vaughan, D. G.: Overview of areal changes of the ice shelves on the Antarctic Peninsula over the past 50 years, The Cryosphere, 4, 77-98, doi:10.5194/tc-4-77-2010, 2010.

Craven, M., Allison, I., Fricker, H. A., and Warner, R.: Properties of a marine ice layer under the Amery Ice Shelf, East Antarctica, J. Glaciol., 55, 717-728, 2009.

Determann, J., Thyssen, F., and Engelhardt, H.: Ice thickness and sea depth derived from reflection-seismic measurements on the central part of Filchner-Ronne Ice Shelf, Antarctica, Ann. Glaciol., 11, 14-18, 1988.

Fahnestock, M. A., Abdalati, W., and Shuman, C. A.: Long melt seasons on ice shelves of the Antarctic Peninsula: an analysis using satellite-based microwave emission measurements, Ann. Glaciol., 34, 127-133, 2002.

Fahrbach, E., Peterson, R., Rohardt, G., Schlosser, P., and Bayer, R.: Suppression of bottom water formation in the southeastern Weddell Sea, Deep Sea Res. Pt. I, 41, 389-411, 1994.

Forste, C., Schmidt, R., Stubenvoll, R., Flechtner, F., Meyer, U., Konig, R., Neumayer, H., Biancale, R., Lemoine, J. M., Bruinsma, S., Loyer, S., Barthelmes, F., and Esselborn, S.: The GeoForschungsZentrum Potsdam/Groupe de Recherche de Geode- sie Spatiale satellite-only and combined gravity field models: EIGEN-GL04S1 and EIGEN-GL04C, J. Geodesy, 82, 331-346, doi:10.1007/s00190-007-0183-8, 2008.

Fricker, H. A. and Padman, L.: Thirty years of elevation change on Antarctic Peninsula ice shelves from multimission satellite radar altimetry, J. Geophys. Res.-Oceans, 117, C02026, doi:10.1029/2011jc007126, 2012.

Galton-Fenzi, B. K., Maraldi, C., Coleman, R., and Hunter, J.: The cavity under the Amery Ice Shelf, East Antarctica, J. Glaciol., 54, 881-887, 2008.

Glasser, N. F. and Scambos, T. A.: A structural glaciological analysis of the 2002 Larsen B ice-shelf collapse, J. Glaciol., 54, 3-16, doi:10.3189/002214308784409017, 2008.

Griggs, J. A. and Bamber, J. L.: Ice shelf thickness over Larsen C, Antarctica, derived from satellite altimetry, Geophys. Res. Let., 36, L19501, doi:10.1029/2009g1039527, 2009.

Grosfeld, K., Gerdes, R., and Determann, J.: Thermohaline circulation and interaction between ice shelf cavities and the adjacent open ocean, J. Geophys. Res.-Oceans, 102, 15595-15610, doi:10.1029/97jc00891, 1997.

Haran, T., Bohlander, J., Scambos, T., Fahnestock, M., and compilers: MODIS mosaic of Antarctica (MOA) image map: Digital media, National Snow and Ice Data Center., Boulder, CO, USA, 2005.

Hemer, M. A., Hunter, J. R., and Coleman, R.: Barotropic tides beneath the Amery Ice Shelf, J. Geophys. Res.-Oceans, 111, C11008, doi:10.1029/2006jc003622, 2006.

Holland, P. R., Corr, H. F. J., Vaughan, D. G., Jenkins, A., and Skvarca, P.: Marine ice in Larsen Ice Shelf, Geophys. Res. Let., 36, L11604, doi:10.1029/2009g1038162, 2009.

Holland, P. R., Corr, H. F. J., Pritchard, H. D., Vaughan, D. G., Arthern, R. J., Jenkins, A., and Tedesco, M.: The air content of Larsen Ice Shelf, Geophys. Res. Let., 38, L10503, doi:10.1029/2011g1047245, 2011.

Jacobs, S. S.: Bottom water production and its links with the thermohaline circulation, Ant. Sci., 16, 427-437, 2004.

Jarvis, E. P. and King, E. C.: Seismic Investigation of the Larsen Ice Shelf, Antarctica - in Search of the Larsen Basin, Ant. Sci., 7, 181-190, 1995.

Jenkins, A., Dutrieux, P., Jacobs, S. S., McPhail, S. D., Perrett, J. R., Webb, A. T., and White, D.: Observations beneath Pine Island Glacier in West Antarctica and implications for its retreat, Nat. Geosci., 3, 468-472, doi:10.1038/ngeo890, 2010.

Johnson, M. R. and Smith, A. M.: Seabed topography under the southern and western Ronne Ice Shelf, derived from seismic surveys, Ant. Sci., 9, 201-208, 1997.

Jullion, L., Naveira Garabato, A. C., Meredith, M. P., Holland, P. R., Courtois, P., and King, B. A.: Decadal freshening of the Antarctic Bottom Water exported from the Weddell Sea, J. Climate, in press, doi:10.1175/jcli-d-12-00765.1, 2013.

King, E. C., Jarvis, E. P., and Mowse, E. A.: Seismic characteristics of an airgun fired over snow, Cold Reg. Sci. Tech., 21, 201-207, 1993.

Kirchner, J. F. and Bentley, C. R.: RIGGS III: Seismic shortrefraction studies using an analytical curve-fitting technique, Ant. Res. Series, 42, 109-126, 1990.

Kohnen, H.: Uber die Beziehung zwischen seismischen Geschwindigkeiten und der Dichte in Firn und Eis, Zeitschrift fur Geophysik, 38, 925-935, 1972. 
Kohnen, H.: The temperature dependence of seismic waves in ice, J. Glaciol., 13, 144-147, 1974.

Kulessa, B., King, E. C., Barrett, B. E., Jansen, D., Luckman, A. J., and Sammonds, P.: Joint inversion of multi-component seismic and ground-penetrating radar (GPR) data for ice-physical properties, and application to the Larsen C ice shelf, AGU Fall Meeting Abstracts, San Francisco, 2010, C21A-0509, 2010.

Lewis, E. L. and Perkin, R. G.: Ice Pumps and Their Rates, J. Geophys. Res.-Oceans, 91, 1756-1762, doi:10.1029/Jc091ic10p11756, 1986.

Mueller, R. D., Padman, L., Dinniman, M. S., Erofeeva, S. Y., Fricker, H. A., and King, M. A.: Impact of tide-topography interactions on basal melting of Larsen C Ice Shelf, Antarctica, J. Geophys. Res.-Oceans, 117, doi:10.1029/2011JC007263, 2012.

Muto, A., Anandakrishnan, S., and Alley, R.: Subglacial bathymetry and sediment layer distribution beneath the Pine Island Glacier ice shelf, West Antarctica, modeled using aerogravity and autonomous underwater vehicle data, Ann. Glaciol., 54, 27-32, 2013.

Nicholls, K. W., Makinson, K., and Venables, E. J.: Ocean circulation beneath Larsen C Ice Shelf, Antarctica from in situ observations, Geophys. Res. Let., 39, L19608, doi:10.1029/2012g1053187, 2012.

Nost, O. A.: Measurements of ice thickness and seabed topography under the Fimbul Ice Shelf, Dronning Maud Land, Antarctica, J. Geophys. Res.-Oceans, 109, C10010, doi:10.1029/2004jc002277, 2004.

Oldenburg, D. W.: The inversion and interpretation of gravity anomalies, Geophysics, 39, 526-536, 1974.

Pritchard, H. D., Ligtenberg, S. R. M., Fricker, H. A., Vaughan, D. G., van den Broeke, M., and Padman, L.: Antarctic ice loss driven by ice-shelf melt, Nature, 484, 502-505, 2012.

Rignot, E., Casassa, G., Gogineni, P., Krabill, W., Rivera, A., and Thomas, R.: Accelerated ice discharge from the Antarctic Peninsula following the collapse of Larsen B ice shelf, Geophys. Res. Let., 31, L18401, doi:10.1029/2004g1020697, 2004.

Rignot, E., Velicogna, I., van den Broeke, M. R., Monaghan, A., and Lenaerts, J.: Acceleration of the contribution of the Greenland and Antarctic ice sheets to sea level rise, Geophys. Res. Let., 38, 5, L05503, doi:10.1029/2011g1046583, 2011.

Roethlisberger, H.: Seismic exploration in cold regions, Pt II ed., Cold Regions Engineering, Section A2a, U.S. Cold Regions Research and Engineering Laboratory, Hanover, N. H., 1972.

Rott, H., Skvarca, P., and Nagler, T.: Rapid collapse of northern Larsen Ice Shelf, Antarctica, Science, 271, 788-792, doi:10.1126/science.271.5250.788, 1996.
Rott, H., Rack, W., Nagler, T., and Skvarca, P.: Climatically induced retreat and collapse of northern Larsen Ice Shelf, Antarctic Peninsula, Ann. Glaciol., 27, 86-92, 1998.

Roy, L., Sen, M. K., Blankenship, D. D., Stoffa, P. L., and Richter, T. G.: Inversion and uncertainty estimation of gravity data using simulated annealing: An application over Lake Vostok, East Antarctica, Geophysics, 70, J1-J12, doi:10.1190/1.1852777, 2005.

Scambos, T. A., Bohlander, J. A., Shuman, C. A., and Skvarca, P.: Glacier acceleration and thinning after ice shelf collapse in the Larsen B embayment, Antarctica, Geophys. Res. Lett., 31, L18402, L18402, doi:10.1029/2004g1020670, 2004.

Shepherd, A., Wingham, D., Payne, T., and Skvarca, P.: Larsen ice shelf has progressively thinned, Science, 302, 856-859, 2003.

Skvarca, P., Rack, W., Rott, H., and Donangelo, T. I. Y.: Climatic trend and the retreat and disintegration of ice shelves on the Antarctic Peninsula: an overview, Polar Res., 18, 151-157, 1999.

Sloan, B., Lawver, L., and Anderson, J.: Seismic stratigraphy of the Larsen basin, eastern Antarctic Peninsula, Ant. Res. Series, 68, 59-74, 1995.

Smith, R. T. and Anderson, J. B.: Ice-sheet evolution in James Ross Basin, Weddell Sea margin of the Antarctic Peninsula: The seismic stratigraphic record, Geol. Soc. Am. Bull., 122, 830-842, 2010.

Swithinbank, C. W. M.: Ice shelves, Geograph. J., 121, 64-76, 1955.

Talwani, M., Worzel, J. L., and Landisman, M.: Rapid gravity computations for two-dimensional bodies with application to the Mendocino submarine fracture zone, J. Geophys. Res., 64, 49$59,1959$.

Tinto, K. J. and Bell, R. E.: Progressive unpinning of Thwaites Glacier from newly identified offshore ridge: Constraints from aerogravity, Geophys. Res. Let., 38, L20503, doi:10.1029/2011g1049026, 2011.

Vaughan, D. G. and Doake, C. S. M.: Recent atmospheric warming and retreat of ice shelves on the Antarctic Peninsula, Nature, 379, 328-331, doi:10.1038/379328a0, 1996.

Vaughan, D. G., Marshall, G. J., Connolley, W. M., Parkinson, C., Mulvaney, R., Hodgson, D. A., King, J. C., Pudsey, C. J., and Turner, J.: Recent rapid regional climate warming on the Antarctic Peninsula, Clim. Change, 60, 243-274, 2003.

Voigt, D., Peters, L. E., and Anandakrishnan, S.: "Georods": the development of a four-element geophone for improved seismic imaging of glaciers and ice sheets, Ann. Glaciol., 54, 142-148, 2013. 